\title{
The Nile-Horn Nexus: Is a New Shatter Belt in the Making?
}

\author{
Aklilu Gebretinsae Andemikael \\ PhD Candidate, Department of International Relations, School of International and Public Affairs, Jilin University, People's \\ Republic of China
}

\begin{abstract}
By using a Shatter Belt Theory as a conceptual framework and a qualitative analysis, this research attempts to answer the question if a new shatter-belt region is in the making as a result of the growing connection between the Nile water politics, the geo politics of the Horn of Africa and presence of foreign powers in the Nile-Horn Region.

A Shatter Belt Theory provides the opportunity to critically expound various patterns of interactions within a certain region that is endowed with plentiful natural resources, has geostrategic importance, gulped in interstate and intrastate conflicts and when these fundamental reasons cumulatively make the region prone to a number of interventions by both regional, extraregional and global powers.

This research concludes that the Nile-Horn region has all the core elements that all Shatter Belt regions have. The abundant water resources and other natural resources it has; its strategic importance; the multi-dimensional conflicts among states and within the states; as well as the pervasiveness of intervention from regional and extra-regional states all make this Region quite similar with its neighboring shatter belt regions of SubSaharan Africa and the Middle East. Hence, the Nile-Horn fits to be called a shatter belt region.
\end{abstract}

Key words: complex interactions; hydro politics; interventions; Nile-Horn nexus; shatter belt

\section{INTRODUTION}

$\mathrm{F}$ clarity sake, the Nile-Horn region on one side comprises the Horn of African countries of Djibouti, Eritrea, Ethiopia and Somalia, the quasi-independent states of Puntland and Somaliland. Besides, included in this Region are Egypt, South Sudan and Sudan. The Nile-Horn Region is home to almost 298 million people i.e. 21 percent of the total population in Africa (World Population Review, 2021). Ethiopia and Egypt are respectively the second and the third most populous countries in Africa and are the $12^{\text {th }}$ and $14^{\text {th }}$ in the world. The region covers 5, 391, 020 sq km i.e. 17.8 percent of the African landmass (ibid).

The Nile-Horn region is home for different peoples and religions. Islam and Christianity are the two most dominant religions. This region is also home for peoples of African origin, Arabs and a mix of both. People with Arab origin are predominantly found in Egypt followed by Sudan. And this makes Sudan a country that exists within two worlds of Arab and African identity (Al Taweel, 2020). From a diplomatic point of view, the headquarters of the African Union and The
Arab League are also in this region making Ethiopia and Egypt the diplomatic hubs in African Union and the Arab League respectively.

The Nile-Horn region exhibits both the salient features of the long standing regional security complexes of the Horn of Africa, the Red Sea region and the growing tension emanating from Nile Hydro politics. The Nile-Horn region is known for international conflicts, civil wars of ethnic and tribal origins and intra-state alliances and counter-alliances. As a result, this Region is the most conflict-ridden region in the world. Markakis (2003) correctly described the Horn as the 'Horn of Conflict' as well as the 'Horn of Crisis'. Cohen on his side stresses that the numerous interstate conflicts in the Horn region could not be seen in separation from "broader disputes over control of natural resources, access to the sea, and reunification of peoples" (Cohen, 2015).

The Nile-Horn region is endowed with natural resources such as oil, natural gas, fertile agricultural lands, vast grazing lands, perennial rivers and other natural resources. These natural resources have been either sources of conflict within and among countries of the Region or have been pull factors for the involvement of extra regional and global powers into the Region. The Red Sea is rich with seabed oil and mineral resource and this can be potentially trigger conflict among the states (Shinn, 2018). Egypt has large reserves of natural gas and is endowed with substantial amount of oil reserves (Cohen, 2015). South Sudan and Sudan have considerable reserves of oil. Similarly, though it has not been commercially exploited Eritrea, Ethiopia and Somalia do have reserves of oil.

In addition, 85 percent of the Nile River originates from Ethiopia (and to some amount from Eritrea) and the rest 15 percent of the White Nile passes through South Sudan. This geographic position makes South Sudan a middle-stream riparian state on the Nile Basin hydropolitics and gives it leverage.

The Nile-Horn region is also endowed with huge fertile agricultural lands. De Waal (2020) notes that East Africa is a potential of food security for the Gulf Countries. And for Saudi Arabia, the Horn is specifically considered as possibility of realizing its "economic diversification and food security"(Beyene,2020). Though disproportionately distributed it might be, there is also a substantial amount of minerals in 
the Nile-Horn region. Potash, gold, copper and other strategic resources are abundant in this region.

The Nile-Horn region has strategic importance that attracts the attention of both powerful countries and countries from the Arabian Gulf. The Region is rimmed by water bodies such as the Pacific Ocean (along the coasts of Somalia-PuntlandSomaliland),BabAl-Mandeb (Djibouti), the Red Sea coast (Djibouti, Egypt, Eritrea, and Sudan) and the 110 miles long Suez Canal (along Egypt). The Suez Canal links the Bab alMandeb with the Mediterranean Sea and handles more than 9 percent of international trade (Shinn, 2020). And this makes the Red Sea an important pathway for global economy.

\section{CONCEPTUAL FRAMEWORK}

Shatter Belt Theory as a concept brings together the elements of traditional geopolitics and conflict theories (Zulfqar, 2018). On a similar token, Cohen (2015) sees the shatter belt region as one of the aspects of the modern-day world geopolitical map and provides the operational definition of the concept of Shatter belt as: "strategically oriented regions that are both deeply divided internally and caught up in the competition between great powers of the geo-strategic realms"(ibid). According to this concept, the reason why external major powers intervene in such shatter belts is that they look for the prevalence of their influence over the region through providing their client states with economic, political as well as military supports (ibid). Commonly, the pull factors for such powers can be strategic importance of the shatter belt region; the natural resources the region is endowed with; the longfestering conflicts that exist among the states in such regions and the domestic problems prevalent within the states. The interferences from neighboring countries are additional factors that exacerbate the fragile nature of such regions. These interventions increase the intensity of the fragmentation by supplying weapons, economic rewards, and political backing to their respective clients (ibid). In shatter belts, conflicts between or within countries usually go beyond their original geographical limits and sooner or later become endemic to neighboring countries. The conflicts in Ethiopia, Somalia, South Sudan and Sudan are cases in point.

Cohen (2015) identifies South East Asia, Sub-Saharan Africa and the Middle East as shatter belts, and leaves the possibility of any further emergence of shatter belts open. Hence, this paper argues that the Nile-Horn is an emergent shatter belt region and it inherits the distinguishing features of two of the three shatter belt regions identified by Cohen. i.e. SubSaharan Africa and the Middle East and as well it is highly influenced by the 'spillover effects' of the dissension and competition that is prevalent in the Middle East among the Gulf Cooperation Council (GCC) countries as well as Iran, Turkey and others.

Besides the shatter belt theory, to elaborate the patterns of interactions as well as interventions in the Nile-Horn region, the concept of three layers of states by Mahmood (2019) has been integrated into the analysis. The three layers are: The global actors, the Arabian Gulf states, as well as states on the Western side of the Red Sea. In light of the above analysis, attempt has been made to explicate the argument of this research paper that Nile-Horn is an emerging shatter belt region.

\section{BACKGROUND}

To understand the present, it is relevant to examine the second half of the $19^{\text {th }}$ century during which most of the states in this region came into existence. During this particular period of time, the region became the location of stern expansionist competition among local and foreign powers. Egypt, Great Britain, France and Italy came one after another with the objective of controlling the Horn region. The presence and involvement of Egypt in this region was principally to control waters of the Nile River. However, after sustaining a heavy defeat by the then Abyssinian king, Egypt's imperial plans were shattered in the Nile-Horn region, except in Sudan. The imperial power vacuum created by the absence of Egyptians was filled by the Italians. Italy was encouraged by the British so that it would frustrate and counter-balance France's move in this region. In 1869, the Italians got a grip in Assab - one of the ports of the present day Eritrea. The French were planning to expand from adjacent Obock (present day Djibouti), till then a fuelling station for their naval forces travelling to and from the Far East. French grand plan was to control the source of the Nile via the then Abyssinia (present day Ethiopia) into Western Africa. The British in their attempt to thwart the French move persuaded the Italians to further expand into the coasts of the Red Sea and this ended up with Italian occupation of Massawa (another port in Eritrea) in the year 1885 . The Italians gradually penetrated to the main land Eritrea and in 1890 established the Italian colony of Eritrea.

On another decisive development, the downfall of the Mahdist state in September 1898 in Sudan led to the emergence a colony of Anglo-Egyptian Sudan - a condominium colony between Egyptians and the British. The British also had another colony - the British Somaliland.

Due to many reasons, the French limited their presence in the small territory called French Somaliland (the present day Djibouti). Italy remained in possession of both Eritrea and the Italian Somaliland. Surrounded by the European colonies was an African empire called Ethiopia - an empire that competed and fought against the regional and colonial powers; went into alliances and counter-alliances with regional and extra regional powers and at last took the present day borders through the successive agreements it signed with colonial powers.

As elsewhere in Africa and other former colonies, the borders of the Nile-Horn states were drawn in total disregard of the wishes and whims of the colonized people. These illogical borders didn't take into consideration the ethnic, religious and cultural composition of the diversified societies these states 
encompass. Hence, most post-colonial states in the Nile-Horn region faced challenges from within their people and also confronted with their immediate neighbors. A lot of ethnic groups were divided into two or more states paving the way for the emergence of irredentist movements as well as irredentist claims by states. For example the Ethiopian empire of the $19^{\text {th }}$ Century, although remained independent, unfortunately was unable to secure an access to the sea. This reality, latter on led to Ethiopia irredentist claim on Eritrea. Ethiopia's occupation of Eritrea led into the thirty years devastating war that claimed the life of hundreds of thousands people from both sides.

Most of the states in many aspects became multi-ethnic in composition, making the nation building process a hectic and strenuous task. 'Legitimacy deficiency' has been the distinguishing feature of many of these states and this in turn undermined the task of national integration.

During the cold war, the Nile-Horn region was either under the direct or indirect influence of both the then superpowers USA and the USSR. The pattern of interaction between the super-powers was clear. As it did everywhere else, the end of the cold war brought drastic changes in the Nile-Horn region. The region has significantly been reconfigured. Eritrea achieved its independence from Ethiopia. After the downfall of the military government, Somalia was drenched into the quagmire of civil war and disintegration. The self-proclaimed de facto state of Somaliland and a quasi-autonomous entity of Puntland have seceded from Somalia. The political map of Sudan has also been changed after South Sudan separated from Sudan in 2011. In the Nile-Horn region, only Egypt and Djibouti are the exceptions in the post-cold war reconfiguration of states. To understand the Nile-Horn nexus and thereby expound the shatter belt argument as applied to this region, it is necessary to identify the salient features of it so that to support the argument.

\section{IV.DISCUSSION}

The Nile-Horn region has a number of core elements that makes it fit to a shatter belt region. Civil wars that reflect ethnic and tribal conflicts; the squabbles for power; intraregional intervention on domestic affairs of each other; interstate conflicts related to resource conflict such as oil, water and other natural resources; inter-state conflicts because of territorial claims and border related issues; conflicts due to irredentism and others are all the intra-regional level conflictual relations that make collaborative development too difficult and also pave the way for the involvement of other countries from near and afar.

Hydro-politics is becoming one of the factors that make this region susceptible to conflict. Retrospectively speaking, the desire to control the source of the Nile and ensuring the safe flow of the waters of the Nile has been a top priority agenda in the history of Egypt. Hence, the Nile-Horn nexus in the aspect of hydro-politics is not a new phenomenon. But, since the last decade, hydro politics has become a noticeable component of the geo-strategic and international relations landscape of the Nile-Horn region.

The Ethiopian plateau is the water reservoir of the Nile basin in general and the Eastern Nile Sub Basin in particular. Ethiopia has geographic leverages on the downstream countries of Egypt and Sudan. Given that its water projects are successfully implemented, it will generate Ethiopia tremendous influence in the Nile-Horn region. Because of the water security related concerns they have, both Sudan and Egypt see Ethiopia's move as a threat (Al Taweel, 2020). Of the 84 billion cubic meter $(\mathrm{bcm})$ average annual flow of the Nile, according to the 1929 Colonial Period Water Agreements, Egypt and Sudan were respectively allotted with $48 \mathrm{bcm} /$ year and $4 \mathrm{bcm} /$ year. The 1959 Agreement ended in a voluminous increment of water allocation $55.5 \mathrm{bcm}$ and $18.5 \mathrm{bcm}$ for Egypt and Sudan respectively (Wolf, 1996). Taking into account that a substantial amount of the waters of the White Nile are lost to evaporation and seepage in the swamps of southern Sudan (Kameri-Mbote,2007), the downstream countries of Sudan and Egypt get the most proportion of their waters from the Blue Nile. Till recently, thanks to the Colonial Period Water Treaties that granted a lion's share of the waters of the Nile to Egypt and Egypt's multi-dimensional power capabilities it had, the country till recently was a hydro-hegemon on the Nile hydro politics. But, Egypt's hydro-hegemony is being challenged by Ethiopia, a country that contributes the largest amount of water to the Nile. Sudan is geographically situated between Ethiopia and Egypt and it had been literary 'bandwagoning' on Egypt's versatile dominance and has been benefiting from the waters of the Nile - if not equivalent to that of Egypt. Additionally, the Juba and Shebelle rivers flow southwards from Ethiopia providing the Somali plains with their only permanent source of water. Though hydro-politics hasn't become a top agenda, in the future these two rivers possibly will be bone of contention between Somalia and Ethiopia. The Colonial Period Water Treaties of the Nile were signed when South Sudan was part of the 'proper Sudan'. Hence, the issue of apportionment is yet to be solved on who shares how much of the waters of the Nile.

There are a number of unsettled border conflicts and territorial claims in the Nile-Horn region. The Nile-Horn region has a number of unsettled issues that emanate from territorial claims. Surprisingly, these conflicts are in many ways direct products of the illogical and arbitrary borders drawn by the colonial powers.

Egypt and Sudan squabble on the Halayeb-Shalateen Triangle. Territorial claims on the fertile Fashiqa Triangle have also recently led into skirmishes between Sudan and Ethiopia. Sudan and South Sudan also have unsettled issues on the oil rich region of Abiyey (Cohen, 2015). Despite the normalization of relations between them, the border issue between Eritrea and Djibouti has not yet been resolved 
(Mahmood, 2019). Similarly, even though Eritrea and Ethiopia have already normalized their relations, the border has not yet been demarcated as per the decisions of the Eritrea Ethiopia Border Commission (EEBC).

Another distinctive feature of the Nile-Horn Region is that it has experienced many conflicts and confrontations that emanate from irredentism. In many ways, the majority of the states in Nile-Horn region still remain in the grip of conflicts driven specifically by the aspiration to attain congruence between a state and a nation. Post independent Somalia's irredentist claim on the territories of the neighboring countries of Djibouti, Ethiopia, and Kenya is a typical example. For Somali nationalists, the 1960s Somali state was much smaller than they longed for. They rather sought, in the words of Clapham that "independence for a single united Somali state that would bring all Somalis together under a common jurisdiction" (Clapham, 2017). Somalia's attempt to reintegrate its 'lost territories' had led into two rounds of war with Ethiopia in 1964 and 1977. Ethiopia's invasion of Somalia in 2006 was primarily a pre-emptive counter irredentist move to preclude any would be revival of Greater Somali's ambition, though the term counter-terrorism was frequently used as a pretext to justify the Ethiopian invasion.

By the same token, Ethiopia's claim on Eritrea in the 1950s is an additional pertinent example of irredentism. In reference to the 'no war, no peace' foreign policy of Ethiopia on Eritrea prior to the oust of the Tigray People's Liberation Front-led government in Ethiopia, Bruton called upon the US to reject "Ethiopian irredentist claims on Eritrea" and pointed out that "the threat to Eritrea from Ethiopia is genuine and pressing ended" (Bruton, 2016). Ethiopia's land locked status has been and will most probably continue to be as the main motive for its 'claim' on Eritrea.

In reference to the mounting tension and concentration of foreign military forces on the Red Sea Region, Sola-Martin observes that the Red Sea is "governed by an alphabet soup of international agreements and peppered with dozens of strategic ports and military bases" (Sola-Martin, 2020). The recent year's military presence of world powers in the Red Sea zone signifies the strategic importance of the Red Sea (Mahmood, 2019) by making the Nile-Horn region the center of contest and competition among extra-regional powers.

In his attempt to explicate the constellation of military presence of many state actors on the Red Sea region Mahmood (2019) comes up with three layers of states that are part and parcel of the complex interaction. These three layers of states are namely: The global actors, the Arabian Gulf states, as well as states on the western side of the Red Sea. But, the tendency of establishing military bases and developing ports (port politics) has not been limited only to the Red Sea Region but it goes beyond this geographical area and extends into the gamut of the whole Nile-Horn region.
To make the above approach fit to the purpose of this study, it is imperative to take into account all the states of the NileHorn region into the discussion. Accordingly, the first layer of states comprises all the Nile-Horn states. These countries have their respective national interests that may be complimentary to each other, divergent or in the worst case mutuallyexclusive against each other. These certainties make the relation among themselves plus with the second and third layer states to have a complex pattern. The majority of the states in the second and third layers do have military bases in the Nile-Horn region. In addition, these countries have interests on port-related issues and investments in different sectors within the Nile-Horn region.

The second layer: Embraces the oil-rich Arabian Gulf countries such as Saudi Arabia, United Arab Emirates, Qatar, and Oman and to a limited extent Iran. The second layer states belong to the Middle East Shatter Belt region and their rivalry 'spills over' to the Nile-Horn region. Saudi Arabia and UAE in unison stand against Qatar and Turkey. The Nile-Horn countries lose as well as benefit from their interaction with the second layer countries.

In the diplomatic arena, UAE was instrumental in the 2018 Peace Agreement between Eritrea and Ethiopia that ended the 18 years stalemate. Former Sudanese president Al-Bashir's attempt to give naval base to Iran is worth mentioning of an act of "pulling the strings of allies for his benefit", thus putting Sudan under the grudge of Saudi-Emeriti coalition (Al Taweel, 2020). In the words of De Waal, the Arab countries' connection in the region is "tactical rather than principled multilateralism" (De Waal, 2020).

Saudi Arabia, the largest oil producer in the world, has the ambition to become a regional power both in the Middle East and also in Red Sea region. And this ambition creates an asymmetrical relationship between Saudi Arabia and the NileHorn region countries. One aspect of Saudi Arabia's influence is the presence of its military bases in the states of the Region. Saudi Arabia has already agreed to set up military base in Djibouti (Mahmood, 2019). For similar purposes, it has already signed agreements with Sudan and Somalia (Maru, 2017). Saudi Arabia, in its anti-Houthi war in Yemen, got support from almost all countries in the Nile-Horn region. These countries are namely Djibouti, Eritrea, Egypt, Somalia, Somaliland and Sudan (Maru, 2017).The 'Saudi Initiative' that paved the way for the establishment of the Red Sea Association, among others, has the objective of ensuring Saudi-led security in the Red Sea zone.

UAE, a strong strategic ally of Saudi Arabia, gives primacy to the control of ports over the Red Sea (Sola-Martin, 2020) as well as on the Gulf of Aden (Shinn, 2018). And this, in some way portends that the country's larger strategic competition with Middle Eastern states (Abdi, 2017). UAE is the largest partner of Somalia in trade sector (Elmi and Mohammed, 2016). It has signed an agreement with Somaliland to establish a military base at Berbera, and has strong relations 
with Puntland (Shin, 2018). But, later on, the plan to set up military base in Berbera was cancelled in early 2020 (SolaMartin, 2020). UAE till recently had military base in Eritrea (Shinn, 2018). UAE's relation with the quasi-independent states of Puntland and Somaliland is resented by the Somali Federal government.

Additionally, both Saudi Arabia and the UAE want to secure the export of their oil, to impede the presence of Iran on the Nile-Horn Region and also to get rid of the influence of the Turkey-Qatar-Oman axis. Iran on its side, to counter balance Saudi Arabia and UAE covets to establish military bases in the Nile-Horn region. Saudi Arabia and UAE do not want Iranian presence in the Western Red Sea (Beyene, 2020) consequently making the Horn 'a battle field for dominance" (Maru, 2017). Qatar's interest is similar to that of Iran and it wants to counter-balance the Saudi-Emeriti-axis and thereby enhancing its influence in the Nile-Horn region. In so doing, it went into alliance with Iran and also forged close relations with Sudan, Djibouti, Somalia and others. Besides Turkey, Qatar has been involved in the development of the port of Suakin in Sudan with an expenditure of US\$ 4 billion (Mahmood, 2019). Somalia provides a good example of 'the reverberation of the struggle for influence' undergoing among Saudi Arabia and UAE on one side and Qatar and Turkey on the other side. This struggle has weakened the struggle of the Federal government of Somalia against al-Shebab (Estelle, 2018).

Yet interestingly enough, the states in the Nile Horn region have developed their own mechanisms to capitalize the rivalry among the Saudi-Emeriti Coalition and the Turkey-Qatari axis. De Waal observes that Somali elites are playing the game of balancing interests in the political market place and Djibouti being the most skillful in balancing its interests "by leveraging its strategic position to avoid overly dependent on any single foreign patron" (De Waal, 2020). Additionally, Djibouti "keeps its neighbors alert by hosting military bases for a multitude of foreign actors" (Beyene, 2020).

The third layer: The states in the third layer are not geographically proximate to the Nile-Horn region. China, USA, Russia, France, and Turkey are the main actors. Additionally, Japan, India, Spain, South Korea, Germany, Italy and others do have their respective vested interests in the Region.

Besides economic and other reasons the third layer countries might have, according to Shin, the main concern of their presence in this region is "to ensure safe passage through the Suez Canal, Red Sea, Bab el-Mandeb, and Gulf of Aden" (Shinn, 2020).

The presence of the USA in this region goes back into the WW II and the cold war period. But, after the end of the cold war and the demise of the USSR, its geo-strategic interests in the region increased. Every year the number of American warships that pass through the Red Sea and Suez Canal is between 35 to 45 . And this makes Egypt and Djibouti strategically more important for US interests. That is why since 2002 the US has established a large military base in Djibouti with the purpose of tackling piracy and counter terrorism (Shinn, 2020). The USA also used Ethiopia in its 'war on terror' in Somalia, though for no avail.

China has neither the history of colonialism nor does it have any record of intervention in the Nile-Horn region states' domestic affairs. Instead, it pursues the policy of nonintervention based on mutual respect. This is appealing to the states of this Region. China also has good relations with all countries of the Nile-Horn region. The Belt and Road Initiative (BRI) and The Forum on China-Africa Co-operation (FOCAC) are indications of the good relation that China has with Africa in general and the Nile-Horn region in particular. Since the end of the Cold War, China's economic and security interest in Nile-Horn Region has greatly increased. Its positive involvement in peace keeping mission under the auspices of the UN (such as between Sudan and South Sudan) as well as the anti-piracy operations in the Gulf of Aden has also been positive (Shin, 2018). China has established Africa's largest Free Trade Zone in Djibouti, and has financed the construction of the new Addis Ababa-Djibouti railway (Beyene, 2020). It also has huge investment in the mining sector in Eritrea. China is a major investor in the oil extraction sector in Sudan and South Sudan and has so far cumulatively invested more than $\$ 30$ billion (Mourad, 2019). In the same way, China has enormous investments in Egypt.

The USA has geo-strategic competition with China in the Nile-Horn region. For that reason, the US wants to hamper and frustrate China's Belt and Road Initiative (BRI) project. The end result of the increasing Chinese influence in East Africa and Red Sea region will foment the power competition between the US and China in the coming years (Mourad, 2019).

Russia (the then USSR) presence in the Nile-Horn Region goes back to the cold war period and USSR had been an ally of Egypt, Ethiopia and Somalia. With the end of the cold war, its presence in the Nile-Horn region eventually diminished. But, recently Russia through the establishment of military bases has come back into the Region with the aim of reasserting itself in the global power competition. For that reason, it is rushing into securing military bases on some of the littoral states. Though not confirmed by the Eritrean side, Mourad (2019) says Russia has a project to establish 'logistics' base in Eritrea, and will soon establish military base in Somaliland (Estelle, 2018). The naval base in Port Sudan already hosts Russian worships and discussion is going on for the establishment of Russian naval base in Sudan (SolaMartin, 2020). Djibouti reportedly rejected Russian request for the establishment of Russian base (Shin, 2018). In recent times, it has established closer relations with Ethiopia. Russia, in union with China, wants political stability and economic development in this region (Shin, 2018). And this 
convergence of interests between China and Russia creates concerns to the USA.

Before the advent of the Europeans, Turkey was a regional power in the region. After the collapse of the Ottoman Empire, its presence in the Nile-Horn region faded away. Turkey's post-cold war return to the Nile-Horn region and its alliance with Qatar is seen with suspicion by Egypt, Saudi Arabia and the United Arab Emirates. Saudi Arabia and UAE suspect that Turkey is working for the revitalization of 'neoOttoman' influence in this region (Shin, 2018). Turkey has military presence on the soils of its strong ally Somalia and may establish one in Suakin (Sudan), and has huge investment in Ethiopia (Beyene, 2020). Additionally, Turkey has also recently been involved in the exploration of oil in Somalia's off shore oil fields; is providing aid, backing the Somali military and is involved in the management of ports and airports in Somalia (Beyene, 2020).

As a former colonizer of Djibouti, France had had significant influence in the domestic politics of Djibouti. Even after Djibouti achieved its independence in 1977, France maintained military base. Currently, France shares its military presence in Djibouti along with many countries. There are also a number of other countries that have geo-strategic and economic interests on the Nile-Horn Region. The countries that have established small permanent military facilities in Djibouti to conduct counter terrorism and anti-piracy operation are Germany, Italy, Spain, and Japan. To counter balance China, Japan has given access to Indian naval vessels in Djibouti (Beyene, 2020).

The cumulative effect of the intersected and complex patterns of interactions among the countries of the three layers makes the Nile-Horn region to be a Shatter Belt region.

\section{CONCLUSION}

The countries of Nile-Horn region, despite they have mutual interests and huge resources that could have been geared into development through capitalizing the comparative advantages they have, unfortunately few has been done to make it a reality. Because of the intra-regional discord and the extra regional and global powers' multi-dimensional vested interests on the Region, the Nile-Horn region has been characterized by underdevelopment, protracted conflicts and confrontations. In a terse statement, what can be said with certainty about the Nile-Horn region is that despite mutuallydependent fate the states might have, the region has unremittingly been sandwiched between domestic problems, intra state conflicts and resultant foreign interventions. And these dynamics make the region an emergent Shatter Belt Region.

\section{REFERENCES}

[1] Abdi, R. (2017). A Dangerous Gulf in the Horn: How the InterArab Crisis Is Fuelling Regional Tensions. International Crisis Group. August 3. 2017https://www.crisisgroup.org/middle-east- north-africa/gulf-andarabian-peninsula/dangerous-gulf-horn-howinter-arab-crisis-fuelling-regional-tensions.

[2] Al Taweel, A. (2020). Sudan -Red Sea basin: Four ways to make or break stability. The Red Sea Dynamics Part 8: The Africa Report. Wednesday, December, 22020 10:02. Accessed on 22 April, 2021 2GMT. https://www.theafricareport.com/51998/sudan-red-sea-basin-fourways-to-make-or-break-stability/

[3] Beyene, A. D.(2020). The Horn of Africa and the Gulf: Shifting power plays in the Red Sea. The Red Sea Dynamics Part 4: The Africa Report. Wednesday, 2 December 2020. Accessed on 22 April 20212 GMT. https://www.theafricareport.com/50499/thehorn-of-africa-and-the-gulf-shifting-power-plays-in-the-red-sea

[4] Bruton, Bronwyn (2021). Eritrea: Coming In from the Cold. Atlantic Council. December 2016: downloaded from 222.27.72.49 on Tue, 02 Mar 2021 15:17:09 UTC;

[5] Clapham, C. (2017) . The Horn of Africa. State Formation and Decay. Oxford University Press, 2017

[6] Cohen, S. B. (2015). Geopolitics: The Geography of International Relations. Maryland, Rowman and Littlefield, $3^{\text {rd }}$ ed.

[7] De Waal, A. ( 2020). The Red Sea: A vital artery for the world economy. The Red Sea Dynamics. Part 3. The Africa Report. Wednesday, 2 December 2020 09:58. Accessed on 22 April, 2021 2GMT. https://www.theafricareport.com/50046/the-red-sea-avital-artery-for-the-world-economy/

[8] Elhance, A.P. (1997). Conflict and Cooperation over Water in the Aral Sea Basin. Studies in Conflict and Terrorism. Vol. 20, No. 2. 1997:

[9] Elmi, A., and Mohammed, S. (2016). The Role of the GCC Countries in Ending Piracy in the Horn of Africa. Arab Center for Research \& Policy Studies . Sep 2016 downloaded from 222.27.72.49 on Tue, 02 Mar 2021 15:33:58 UTC

[10] Estelle, E. (2018). Ethiopia's Strategic Importance: US National Security Interests at Risk in the Horn of Africa. American Enterprise Institute (AEI). September 12, 2018

[11] White, G.W. (2009). Irredentism: Frostburg State University, Frostburg, MD, USA.

[12] Kameri-Mbote, P. (2007). Water, Conflict and Cooperation: Lessons from the Nile River Basin, Woodrow Wilson International Center for Scholars, Navigating Peace no. 4. 2007 p: 24

[13] Li, A., et al (2016). African Studies in China in the $21^{\text {st }}$ Century: A Historiographical Survey. Brazilian Journal of African Studies, 1, no. 2. 2016. pp:48-88.

[14] Mahmood, S. O. (2019). Competition, Cooperation and Security in the Red Sea. Institute for Security Studies. East Africa Report 24, August. 2019.

[15] Markakis, J. (2003). The Horn of Conflict. Review of African Political Economy. Sep. 2003. pp: 359-362

[16] Maru, M.T. (2017). A Regional Power in the Making: Ethiopian Diplomacy in the Horn of Africa. South African Institute of International Affairs. June 2017. Downloaded from 222.27.72.49 on Tue, 02 Mar 2021 15:18:10 UTC

[17] Mourad, H. (2019). Bab Al-Mandeb Strait: Sino-American duel in the Red Sea. Thursday 3 Jan 2019 ahramonline https://english.ahram.org.eg/News/321123.aspx

[18] Servant, J. C. ( 2009). China's Trade Safari in Africa. Le Monde Diplomatique. http://mondediplo.com/2005/05/11 chinafrica: 2009, accessed 18 March 2021

[19] Shinn, D. (2018). Red Sea Region, Competing Outside Powers Complicate U.S. Interests. The United States Institute of Peace. Wednesday, $\quad$ December 2018 https://www.usip.org/publications?publication_type $\% 5 \mathrm{~B} 0 \% 5 \mathrm{D}=1$ 2

[20] Shinn, D. (2020). The Red Sea: A magnet for outside powers vying for its control. The Red Sea Dynamics Part 9: The Africa Report. 27 November 2020 11:52. Accessed on 22 April, 2021 2GMT https://www.theafricareport.com/52152/the-red-sea-amagnet-for-outside-powers-vying-for-its-control/ 
[21] Sola-Martin, A. (2020). Ports, military bases and treaties: Who's who in the Red Sea? The Red Sea Dynamics Part 2. The Africa Report. 2 December 2020 09:56. Accessed on 22 April, 2021 2GMT https://www.theafricareport.com/49957/ports-militarybases-and-treaties-whos-who-in-the-red-sea/.

[22] Wolf, A. (1996). Middle East Water Conflicts and Directions for Conflict Resolution. Food, Agriculture, and the Environment Discussion Paper 12. International Food Policy Research Institute. March, 1996. P: 3

[23] World Population Review (2021). www.wpr.org visited on April 10, 2021

[24] Zeitoun, M. and Warner, J. (2006). Hydro-hegemony: A Framework for Analysis of Transboundary Water Conflicts. Water Policy. vol 8, no 5, 2006 pp:435-460

[25] Zulfqar, S. (2018). Competing Interests of Major Powers in the Middle East: The Case Study of Syria and Its Implications for Regional Stability. Journal of International Affairs: Spring, 2018 Vol XXIII- no 1.Centre for Strategic Research 